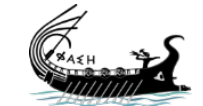 \\ journal.phaselis.org \\ open 2 access journals}

Atıf Düzeni

M. R. Tunç - M. Yavuz, “Phaselis Antik Kenti ve Yakın Çevresinin Herpetofaunası: 2014-2015
Yılları Çalışmaları”. Phaselis II (2016) 193-208. DOI: 10.18367/Pha.16013

Geliş Tarihi: 04.03.2016 | Kabul Tarihi: 20.04.2016 | Elektronik Yayın Tarihi: 05.09.2016

Editörya
PHAS LLIS

Disiplinlerarası Akdeniz Araştırmaları Dergisi

Journal of Interdisciplinary Mediterranean Studies
Volume II (2016)

\section{Phaselis Antik Kenti ve Yakın Çevresinin Herpetofaunası: 2014-2015 Yılları Çalışmaları}

The Herpetofauna of the Ancient City of Phaselis and its

Territorium: Studies undertaken in 2014 and 2015

Mehmet Rızvan TUNÇ - Mustafa YAVUZ

PHASELIS: Disiplinlerarası Akdeniz Araştırmaları Dergisi'nde bulunan içeriklerin tümü kullanıcılara açık, serbestçe/ücretsiz "açık erişimli" bir dergidir. Kullanıcılar, yayıncıdan ve yazar(lar)dan izin almaksızın, dergideki makaleleri tam metin olarak okuyabilir, indirebilir, dağıtabilir, makalelerin çıktısını alabilir ve kaynak göstererek makalelere bağlantı verebilir.

PHASELIS: Disiplinlerarası Akdeniz Araştırmaları Dergisi uluslararası hakemli elektronik (online) bir dergi olup değerlendirme süreci biten makaleler derginin web sitesinde (journal.phaselis.org) yıl boyunca ilgili sayının içinde (Volume II: Ocak-Aralık 2016) yayımlanır. Aralık ayı sonunda ilgili yıla ait sayı tamamlanır.

Dergide yayımlanan eserlerin sorumluluğu yazarlarına aittir.

Phaselis Research Project

www.phaselis.org 


\title{
Phaselis Antik Kenti ve Yakın Çevresinin Herpetofaunası: 2014-2015 Yılları Çalışmaları
}

\author{
The Herpetofauna of the Ancient City of Phaselis and its Territorium: \\ Studies undertaken in 2014 and 2015
}

\author{
Mehmet Rızvan TUNÇ* Mustafa YAVUZ**
}

\begin{abstract}
Öz: Bu çalışmada Phaselis antik kenti ve yakın çevresinde yayılış gösteren herpetofauna elemanları değerlendirilmiştir. Ayrıca; sahada gözlemlenen bazı türlerin genel özellikleri ve fotoğrafları da sunulmuştur. Bu kapsamda, 2014-2015 yılları arasında sahada yapılan arazi çalışmaları sonucunda memelilerden 36 tür tespit edilmiştir. Bu türlerin koruma statüleri incelendiğinde; herpetofauna için 1 türün IUCN statüsü belli değilken, 1 tür CR, 1 tür EN, 3 tür NT, 1 tür VU ve geri kalan 29 tür de LC kategorisinde yer almaktadır. Bu memelilerden 25 tanesi Bern Sözleşmesi listelerinde Ek 2'de (Kesin Olarak Koruma Altına Alınan Türler), 9 tanesi de Ek 3'te (Korunan Türler) yer almaktadır. Bu çalışma dönemindeki mevcut durumları, tür sayıları ve bazı özellikleri incelenen herpetofauna elemanlarının tür sayısı ve durumları ileride yapılacak daha geniş kapsamlı çalışmalar sonucunda değişebilecektir.
\end{abstract}

Anahtar Sözcükler: Phaselis · Amfibi · Sürüngen · Herpetofauna · Antalya

Abstract: In this study the terrestrial Herpetological fauna of the Ancient City of Phaselis and in its Territorium were evaluated. Also in this study the general properties of some of the species observed in the field are given together with a photograph. In consequence of the field studies conducted during 2014-2015: 36 species of amphibians and reptiles were identified. Considering the conservation status of these species; the IUCN status for the herpetofauna: 1 species located in category CR, 1 species located in category EN, 3 species located in category NT, 1 species located in category VU, 29 located in category LC and 1 species is in an undefined category, the Bern Convention status for the herptils: 25 species located in Appendix II (Strictly Protected Fauna Species) category, 9 Species located in Appendix III (Protected Fauna Species) category. The current situation recorded during the course of this study, the number of the species and some features of the fauna, will vary through the wider range of future studies examining the fauna and their environmental situation.

Keywords: Phaselis · Amphibian · Reptilian · Herpetofauna · Antalya

\section{Giriş}

Omurgalı hayvanlar yeryüzünde çok geniş coğrafik alanlara yayılmış, özellikle sucul ortamlardan uzaklaşabilip karasal yaşama da adapte olarak ekosistemin önemli parçaları haline gelmişlerdir. Omurgalı hayvanlar içerisinde karasal yaşama ilk olarak adapte olabilmiş sınıf amfibiler olup, birçok taksonunun hayatlarının bir kısmını karada, bir kısmını ise suda geçirmeleri nedeniyle iki yaşamlılar anlamına gelen bu adı almışlardır. İki yaşamlılar sucul ortamda yaşamaya uygun özelliklerle yaşamlarına başlarlar ve metamorfoz geçirerek karasal yaşama uygun özellikler kazanırlar.

* Uzman, Akdeniz Üniversitesi, Fen Fakültesi, Biyoloji Bölümü, Antalya. rtunc@akdeniz.edu.tr

** Yrd.Doç.Dr., Akdeniz Üniversitesi, Fen Fakültesi, Biyoloji Bölümü, Antalya. myavuz2006@gmail.com 
Bu sayede de suya yakın olan, nemli habitatlarda yayılma imkânı elde etmişlerdir. Bu nedenle derelerden nemli vejetasyonlara, sulu mağaralardan çöllerin nemli kısımlarına kadar çok çeşitli habitatlarda amfibilere rastlanılabilmektedir.

Bunun yanında, en yakın akraba grup olan sürüngenler ise gerek bazı durumlarda amfibilerin predatörleri olmaları, gerek de kuş ve sürüngenler için önemli besin kaynakları konumunda bulunmaları nedeniyle sağlıklı bir ekosistem için vazgeçilmez unsurlardır. Aynı zamanda, karasal yaşamın getirdiği fiziksel zorluklar ve su kıtlığı gibi faktörlere karşı daha dayanıklı oluşları neredeyse yeryüzündeki tüm habitatlarda yayılış gösterebilmelerini sağlamıştır. Çöllerden, kuru ve nemli toprak içlerine, nemli ormanlardan, mağaralara ve akarsulara, hatta denizlere kadar çok geniş alanlarda yayılış göstermektedirler.

Ülkemizde de, su ve nemin bulunduğu hemen hemen her yerde bulunabilen amfibiler ve de karasal-sucul neredeyse tüm habitatlarda görülebilen sürüngenler ilgi odağı konumundadırlar. Nispeten daha kolay elde edilmeleri, iz ve işaretleri vasıtasıyla daha kolay ulaşıımaları, sayıca bol oluşları vb. nedenlerle birçok araştırmada hedef organizma konumundadırlar. Bazı adaların ve önemli tabiat alanlarının ekosistem ve habitatının mevcut durumu ile ilgili olarak araştırmacılara önemli bilgiler sunabilen amfibiler ve sürüngenler gerek sistematik gerek ekolojik, gerekse ekobiyolojik çalışmalarda model unsur olarak yer almaktadırlar. Bu bakımdan ülkemizin çeşitli yerlerinde muhtelif zamanlarda yapılmış çok sayıda çalışma mevcuttur ${ }^{1}$.

Ülkemizde geniş ölçekte çalışılan, bilim insanlarının ilgisini çeken amfibi ve sürüngenlerle ilgili olarak çalışma alanımız olan Phaselis antik kenti ve teritoryumunda konuya özgü olarak yapılmış mevcut çalışmalar ${ }^{2}$ yetersizdir. Bu bakımdan, sahadaki amfibi ve sürüngen varlığını irdeleyen yoğun herpetolojik çalışmalara ihtiyaç duyulmaktadır. Bu ihtiyacı gidermek için bu çalışmada sahanın herpetofaunistik durumu irdelenmiş ve sahanın mevcut durumuyla ilgili güncel bilgiler sunulmuştur.

\section{Materyal ve Metot}

Önceki yıllarda, projenin başlamasıyla birlikte, ilk olarak mevcut literatüre yenileri eklenerek, suculkarasal omurgasızlar, amfibi-sürüngenler ve de kuşlar-memeliler ile ilgili bazı yeni bilgiler derlenmişti. Bu dönemde ayrıca literatür taramasına başlanmış ve yeni literatür verileri ile birlikte güncel kaynaklar da derlenmiştir. Ayrıca, Akdeniz Üniversitesi, Fen Fakültesi, Biyoloji Bölümü, Zooloji Anabilim Dalı öncülüğünde, söz konusu yöre ve yakın çevresinde 1994'ten günümüze değin yürütülen arazi çalışmaları kapsamında elde edilen veriler yanında araştırmalar özelindeki gözlem ya da örneğe dayalı bulgulardan da yararlanılmıştır ${ }^{3}$. Toplanan tüm bu veriler birlikte değerlendirilerek alanın dönemsel mevcut herpetofauna elemanlarının tespiti yapıımıştır. Arazi çalışmaları sırasında gerekli olacak sırt çantası, portable GPS (global positioning system), pil, fotoğraf makinesi, dürbün, yakalama kepçeleri vb. donanım çalışma başlangııında hazırlanmıştır. Alandan veri toplarken kulla-

1 Bodenheimer 1944; Mertens 1952; Başoğlu - Özeti 1973; Baran 1976; Başoğlu - Baran 1977; Baran 1983; Başoğlu - Baran 1988; Özeti - Yılmaz 1994; Başoğlu et al. 1994; Baran et al. 1996; Baran - Atatür 1998; Öz et al. 1999; Baran et al. 2001; Kumlutaş et al. 2004a; 2004b; Baran 2005; Baran et al. 2012 bunlara örnek olarak sayılabilir. Yine birçok faunistik çalışmada ise (örneğin bk. Demirsoy 1996a; Erdoğan et al. 2002; Düşen et al 2005; Yavuz - Tunç 2015a) diğer omurgalı gruplarıyla birlikte durumları değerlendirilen sınıflar olarak karşımıza çıkmaktadır.

2 Yavuz - Tunç 2015b.

3 Erdoğan et al. 2008. 
nılacak olan formatlar hem dijital hem de basılı ortamda yeniden düzenlenmiş ve çoğaltılmıştır.

Çalışma alanındaki amfibiler nemli, suya yakın ya da su içlerindeki yaşam ortamlarında gözlemlenmiş ve fotoğraflanmış, sürüngenlerin habitatları doğrudan gözlemlerle taranarak tanınıp isimlendirilmiştir. Bu anlamda, herpetofauna türlerinin tespiti için bölge havza bazında değerlendirilmiş, bu doğrultuda teleobjektifli fotoğraf makinesi ve de video kamera kullanılarak amfibi ve sürüngen türleri belirlenmeye çalışılmıştır. Ayrıca, yöre halkıyla görüşülerek amfibi ve sürüngenlerle ilgili bilgi alışverişinde bulunulmuştur. Sürüngenlerin tespiti için hat boyunca gözlem (transekt) ve nokta gözlem uygulamaları yapılmıştır.

Proje alanı ve yakın çevresinde gerçekleştirilen arazi çalışmaları sonucunda saptanan herpetofauna elemanlarının tür tespitleri yapıımıştır. Buna ek olarak, bu türlerin familya ve bilimsel adları, bu adların Türkçe karşııkları, biyotop (habitat) ve (varsa) tehlike kategorileri, tehlike sınıfı açısından değerlendirmesi ve statüleri ile ilgili açıklamalarda da bulunulmuştur. Bu doğrultuda, IUCN (The International Union for Conservation of Nature); ATS (European Threat Status); Bern Sözleşmesi; CITES (Tehlike Altında Olan Yabani Hayvan ve Bitki Türlerinin Uluslararası Ticaretine Iliş̧kin Sözleşme) ve Çevre ve Şehircilik Bakanlığı Doğa Koruma ve Milli Parklar Genel Müdürlüğü Merkez Av Komisyonu 2014-2015 dönemi kararlarından da yararlanılmıştır. Diğer taraftan yörenin herpetofaunası havza bazında ele alınmış, tablolarda sahada bulunabilecek türlere de yer verilmiştir. Bunlara ek olarak yörede kaydedilen yabanıl türler arasında endemik örnekler bulunup bulunmadığı da sorgulanmıştır. Yapılan çalışmada öncelikle gözlem ve fotoğraf temelli fauna kayıtları ile habitat verileri toplanmış, araştııılan fauna elemanları bakımından alanın "hassas fauna türlerinin ve özelliklerinin henüz tam olarak belirlenmemiş olması" nedeniyle örnek alınmamıştır. Böylece toplanan tüm veriler bir arada değerlendirilerek proje alanının herpetofauna elemanlarının dönemsel tespiti yapılmıştır.

\section{Bulgular}

Proje sahasında yapılan çalışmalar kapsamında, alanın karasal omurgalı faunal yapısı incelenmiş, 2014-2015 yılları arasında elde edilen dönemsel bulgular aşă̆ıda sunulmuştur.

Türkiye'de yayılış gösteren yaklaşık 165 kurbağa ve sürüngen türünün 36'sının çalışma sahası ve yakın çevresinde de yaşadığı tespit edilmiş̧ir. Bu türlerden 6'sı kurbağa, 3'ü kaplumbağa, 14'ü kertenkele, 13'si de yılanlara aittir. Bunlardan Lyciasalamandra billae (Beldibi Semenderi) CR [tükenme riski olan]; Deniz Kaplumbağası (Caretta caretta) EN [tehdit altında]; Tosbağa (Testudo graeca) VU [zarar görebilir]; körkertenkele, bukalemun ve sarı yılan (Blanus strauchi, Chamaeleo chamaeleon, Elaphe sauromates) ise NT [sayısı azalıyor] kategorisinde yer almaktadır. Diğer taraftan, kurbağaların (anurlar) tamamı ise IUCN özelindeki LC [düşük risk] kategorisinde yer almaktadır. Ancak bu dönemde tespit edilemese dahi literatür bilgilerine göre; sahada endemik semenderlerden 2 türün bu alanın içinde (Lyciasalamandra bilae ve Lyciasalamandra irfani) yaşadığı bilinmektedir. Bulunan türler bu iki semender hariç geniş yayılımlıdır. İlk bulgularımıza göre semenderler hariç bölgeye özgü endemik ve lokal endemik bulunmamaktadır. Yörenin herpetofaunası dikkate alındığında; 1 türün IUCN statüsü belli değilken, 1 tür CR, 1 tür EN, 3 tür NT, 1 tür VU, 29 tür ise LC, kategorisindedir. Bern Sözleşmesi'nin Kesin Koruma Altında Olan Türler (Ek 2) kategorisinde 25 tür, Koruma Altında Olan Türler (Ek 3) kategorisinde ise 9 tür yer almaktadır (Çizelge 1). Phaselis'in amfibi ve sürüngenleri Türkiye'deki türlerin -şimdilik- yaklaşık \%20'ni oluştururken, ileriki yıllarda yapılan arazi çalışmalarıyla görülen tür sayısına yeni eklemeler yapılabilecektir. Bölgede yaşayan amfibi ve sürüngen türlerine ait bazı türlerin fotoğrafları, be- 


\begin{tabular}{|c|c|c|c|c|c|c|c|c|c|}
\hline \multirow{3}{*}{ Familya } & \multirow{3}{*}{ Latince Adı } & \multirow{3}{*}{ Türkçe Adı } & \multirow{3}{*}{ İngilizce Adı } & \multicolumn{4}{|c|}{ Tehlike Durumu } & \multirow{3}{*}{ MAK } & \multirow{3}{*}{ НАВіТАТ } \\
\hline & & & & \multirow{2}{*}{ IUCN } & \multicolumn{2}{|c|}{ BERN } & \multirow{2}{*}{ CITES } & & \\
\hline & & & & & EK2 & EK3 & & & \\
\hline \multicolumn{10}{|l|}{ KURBAĞALAR } \\
\hline \multirow[t]{2}{*}{ SALAMANDRIDAE } & Lyciasalamandra billae & Beldibi Semenderi & Bille's Lycian Salamander & $C R$ & $x$ & - & - & -- & $\mathrm{O}, \mathrm{C}, \mathrm{K}$ \\
\hline & Lyciasalamandra irfani & Göynük Semenderi & Irfan's Lycian Salamander & - & $x$ & - & - & -- & $\mathrm{O}, \mathrm{C}, \mathrm{K}$ \\
\hline \multirow[t]{2}{*}{ BUFONIDAE } & Bufo bufo & Siğilli Kurbağası & Common Toad & LC & - & $x$ & - & -- & $\mathrm{T}, \mathrm{M}$ \\
\hline & Bufotes variabilis & Gece Kurbağası & Green Toad & LC & $x$ & - & - & -- & Ç,T,M \\
\hline HYLIDAE & Hyla orientalis & Ağaç Kurbağası & European Tree Frog & LC & $x$ & - & - & -- & Ç,M \\
\hline RANIDE & Pelophylax ridibundus & Ova Kurbağası & Eurasian Marsh Frog & LC & - & $x$ & - & -- & $\mathrm{S}$ \\
\hline \multicolumn{10}{|l|}{ SÜRÜNGENLER } \\
\hline CHELONIIDAE & Caretta caretta & Deniz Kaplumbağası & Loggerhead & EN & $x$ & - & - & Ek liste I & $\mathrm{D}$ \\
\hline TESTUDINIDAE & Testudo graeca & Tosbağa & Spur-thighed Tortoise & $\mathrm{VU}$ & $x$ & - & Ekll & Ek liste I & $\mathrm{O}, \mathrm{C}, \mathrm{T}, \mathrm{M}$ \\
\hline GEOMYDIDAE & Mauremys rivulata & Çizgili Kaplumbağa & Western Caspian Turtle & LC & $x$ & - & - & Ek liste I & $\mathrm{S}$ \\
\hline \multirow[t]{2}{*}{ GEKKONIDAE } & Mediodactylus kotschyi & İnce Parmaklı Keler & Kotschy's Gecko & LC & $x$ & - & - & Ek liste I & $\mathrm{O}, \mathrm{T}, \mathrm{M}, \mathrm{K}$ \\
\hline & Hemidactylus turcicus & Yarım Parmaklı Keler & Turkish Gecko & LC & - & $x$ & - & Ek liste I & $\mathrm{O}, \mathrm{T}, \mathrm{M}, \mathrm{K}$ \\
\hline AGAMIDAE & Stellagama stellio & Dikenli Keler & Starred Agama & LC & $x$ & - & - & Ek liste I & $\mathrm{K}$ \\
\hline CHAMAELEONIDAE & Chamaeleo chamaeleon & Bukalemun & Mediterranean Chameleon & NT & $x$ & - & - & Ek liste I & $\mathrm{O}, \mathrm{T}, \mathrm{M}, \mathrm{C}$ \\
\hline ANGUIDAE & Pseudopus apodus & Oluklu Kertenkele & European Glass Lizard & LC & $x$ & - & - & Ek liste I & $\mathrm{O}, \mathrm{T}, \mathrm{M}$ \\
\hline \multirow{4}{*}{ LACERTIDAE } & Anatololacerta danfordi & Toros Kertenkelesi & Anatolian Rock Lizard & LC & $x$ & - & - & Ek liste I & $\mathrm{O}, \mathrm{T}, \mathrm{K}$ \\
\hline & Lacerta trilineata & İri Yeşil Kertenkele & Balkan Green Lizard & LC & $x$ & - & - & Ek liste I & $\mathrm{O}, \mathrm{T}, \mathrm{M}, \mathrm{C}$ \\
\hline & Phoenicolacerta laevis & Hatay Kertenkelesi & Lebanon lizard & LC & - & $x$ & - & Ek liste I & $\mathrm{K}, \mathrm{O}, \mathrm{C}, \mathrm{T}, \mathrm{M}$ \\
\hline & Ophisops elegans & Tarla Kertenkelesi & Snake-eyed Lacertid & LC & $x$ & - & - & Ek liste I & $\zeta \zeta, T, M$ \\
\hline
\end{tabular}




\begin{tabular}{|c|c|c|c|c|c|c|c|c|c|}
\hline \multirow{4}{*}{ SCINCIDAE } & Trachylepis aurata & Tıknaz Kertenkele & Levant Skink & LC & - & $x$ & - & Ek liste I & $\mathrm{O}, \mathrm{T}, \mathrm{M}$ \\
\hline & Trachylepis vittata & Şeritli Kertenkele & Bridled Mabuya & LC & - & $x$ & - & Ek liste I & $T, M, C ̧$ \\
\hline & Ablepharus kitaibelii & İnce Kertenkele & European Copper Skink & LC & $x$ & - & - & Ek liste I & $\mathrm{T}, \mathrm{M}, \mathrm{O}$ \\
\hline & Chalcides ocellatus & Benekli Kertenkele & Ocellated Skink & LC & $x$ & - & - & Ek liste I & $\mathrm{T}, \mathrm{M}$ \\
\hline BLANIDAE & Blanus strauchi & Kör Kertenkele & Anatolian Worm Lizard & NT & - & $x$ & - & Ek liste I & $\mathrm{O}, \mathrm{T}, \mathrm{M}$ \\
\hline TYPHLOPIDAE & Xerotyphlops vermicularis & Kör Yılan & European Blind Snake & LC & - & $x$ & - & Ek liste I & $\mathrm{O}, \mathrm{C \zeta ,M}$ \\
\hline \multirow{9}{*}{ COLUBRIDAE } & Dolichophis caspius & Hazer Yılanı & Yellow-Bellied or Caspian Racer & $\mathrm{LC}$ & - & $x$ & - & Ek liste I & $\mathcal{C}, \mathrm{M}, \mathrm{T}$ \\
\hline & Dolichophis jugularis & Kara Yılan & Large Whip Snake & LC & - & $x$ & - & Ek liste I & $\mathcal{C}, \mathrm{M}, \mathrm{T}$ \\
\hline & Platyceps najadum & İnce Yılan & Dahl's Whip Snake & LC & $x$ & - & - & Ek liste I & $\mathrm{O}, \mathrm{T}, \mathrm{M}, \mathrm{C}$ \\
\hline & Eirenis modestus & Uysal Yılan & Ring-Headed Dwarf Snake & $\mathrm{LC}$ & - & $x$ & - & Ek liste I & $\mathrm{O}, \mathrm{C}, \mathrm{M}, \mathrm{T}$ \\
\hline & Zamenis situla & Ev Yılanı & European Ratsnake & $\mathrm{LC}$ & $x$ & - & - & Ek liste I & $\mathrm{O}, \mathcal{C}, \mathrm{M}, \mathrm{T}$ \\
\hline & Elaphe sauromates & Sarı Yılan & Four-lined Snake & NT & $x$ & - & - & Ek liste I & $O, C \zeta, M$ \\
\hline & Malpolon insignitus & Çukurbaşlı Yılan & Montpellier Snake & LC & $x$ & - & - & Ek liste I & $\mathrm{O}, \mathcal{C}, \mathrm{M}, \mathrm{T}$ \\
\hline & Telescopus fallax & Kedigözlü Yılan & Soosan Snake & $\mathrm{LC}$ & $x$ & - & - & Ek liste I & $O, C ̧$ \\
\hline & Hemorrhois nummifer & Sikkeli Yılan & Leaden-Colored Racer & LC & - & $x$ & - & Ek liste I & $\mathrm{O}, \mathcal{C}, \mathrm{M}$ \\
\hline \multirow[t]{2}{*}{ NATRICIDAE } & Natrix natrix & Yarı Sucul Yılan & Grass Snake & LC & - & $x$ & - & Ek liste I & $\mathrm{S}$ \\
\hline & Natrix tesellata & Sucul Yilan & Tessellated Water Snake & LC & $x$ & - & - & Ek liste I & $\mathrm{S}$ \\
\hline VIPERIDAE & Montivipera xanthina & Şeritli Engerek & Ottoman Viper & $\mathrm{LC}$ & $X$ & - & - & Ek liste I & K \\
\hline
\end{tabular}

Çizelge 1. Proje Sahası ve Yakın Çevresinde Bulunan Kurbağa ve Sürüngen Türlerinin Familyaları, Bilimsel İsimleri, Türkçe-Ingilizce Karşılıkları, Uluslararası Doğal Hayatı ve Doğal Kaynakları Koruma Birliği (IUCN Red List), Bern Sözleşmesi, Nesli Tehlike Altında Olan Yabani Hayvan ve Bitki Türlerinin Uluslararası Ticaretine iliş̧kin Sözleşme (CITES), Merkez Av Komisyonu (MAK) Kararları ile Habitat Statüleri 
Habitat: Yaşam alanları

K: Kayalık ve Taşlık Alanlar, O: Orman, Ç: Çalııı, M: Mera, T: Tarım arazileri, S: Su ve suya yakın yerler, D: Deniz

Tespit şekli: G (Gözlem), L (Literatür)

\section{IUCN:Uluslar arası Doğal Hayatı ve Doğal Kaynakları Koruma Birliği}

CR (Critical) Dogada neslinin tükenme riskinin aşırı derecede yüksek olduğu kabul edilir.Tek tür semenderlerden Lyciasalamandra billae(Beldibi Semenderi)vardır.

EN (endangered): Vahşi yaşamda soyu tükenme tehlikesi çok büyük olan türler. Bu katagoriye giren sadece Deniz Kaplumbağalarından Caretta caretta(Sini Kaplumbağası)'dır.

VU (vulnerable) (Hassas, zarar görebilir): Vahşi yaşamda soyu tükenme tehlikesi büyük olan türler. Proje sahası ve yakın çevresinde bu kategoride yer alan 1 tür Tosbağalardan Testudo graeca (Tosbağa) dür.

NT (nearthreatened): Şu anda tehlikede olmayan fakat yakın gelecekte VU, EN veya CR kategorisine girmeye aday olan türler. Bu katagoride 3 tür Elaphe sauromates(Sarı yılan), Blanus strauchi(Kör kertenkele) ve Chamaeleo chamaeleon(Bukalemun) vardır.

LC (leastconcern) (En düşük derecede tehdit altında): Yaygın bulunan türlerdir, proje sahası ve yakın çevresinde 29 tür dahildir.

\section{BERN: Bern sözleşmesine göre:}

Ek II: Mutlak koruma altında olan türlerdir ve buna 23 tür dahildir.

EK III: koruma altında olan türlerdir ve bu gruba 13 tür girmektedir.

CITES: Covention on International Trade in Endangered Species of Wild Fauna and Flora (Nesli Tehlike Altında Olan Yabani Hayvan ve Bitki Türlerinin Uluslararası Ticaretine Illişkin Sözleşme).

EK-1 Nesilleri tükenme tehdidi ile karşı karşıya bulunan ve bu nedenle örneklerinin ticaretinin sıkı mevzuata tabi tutulması ve bu ticarete sadece istisnai durumlarda izin verilmesi zorunlu olan türleri içerir.

EK-2 Nesilleri mutlak olarak tükenme tehdidiyle karşı karşıya olmamakla birlikte, nesillerinin devamıyla bağdaşmayan kullanımları önlemek amacıyla ticaretleri belirli esaslara bağlanan türleri içerir. 1 tür bu gruba Testudo graeca (Tosbağa) girmektedir.

\section{MAK: Merkez Av Komisyonu kararları}

EK LISTE-1: Orman ve Su İşleri Bakanlığınca Koruma altına alınan yaban hayvanları. Sürüngenlerin tamamı 30 tür bu gruba girer

EK LISTE-II: Merkez av Komisyonunca koruma altına alınan av hayvanları. Bu gruba giren Amfibi ve Sürüngen yoktur.

EK LISTE-III: MAK'ca avına belli edilen sürelerde izin verilen av hayvanları. Bu gruba giren Amfibi ve Sürüngen yoktur.

EK LISTE-IV: illere göre Merkez av Komisyonu tarafından 2013-2014 av döneminde avın yasaklandığı sahalar. Bu gruba giren Amfibi ve Sürüngen yoktur. 


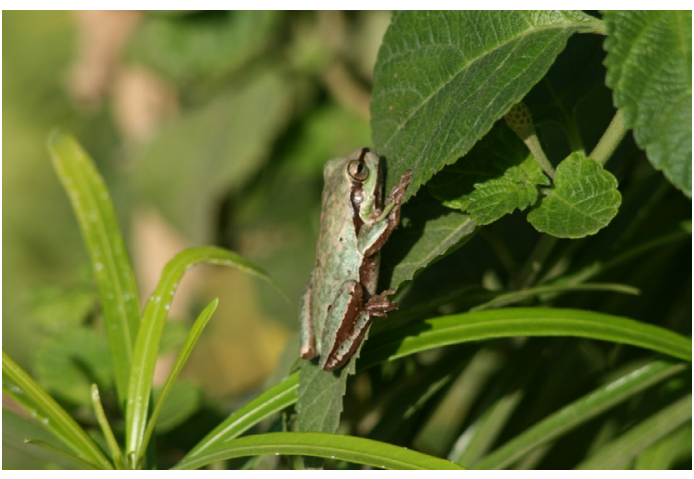

Fig. 1. Antik Kent ve Çevresinde de Görülen, Nemli Yerlerde, Ağaçık ve Çayırlık Alanlarda Bulunan Geniş Yayılımlı Türlerden Olan Ağaç Kurbağası (Hyla orientalis)

timlemeleriyle birlikte aşağıda (Fig. 1-10) verilmiştir ${ }^{4}$.

\section{Hyla orientalis (Linnaeus 1758) Ağaç Kurbağası}

Vücut boyu $5 \mathrm{~cm}$ civarındadır (Fig. 1). Genellikle sırt tarafı yeşil renkte olup pürüzsüzdür. Bulundukları habitatın rengine göre kahverengi ve gri renkte olabilir. Kulak zarı bariz, gözbebekleri yataydır. Burundan başlayan, gözün arkasında devam edip kasık bölgesine kadar uzanan kahverengi bir şeride sahiptir. Bu şerit kasık bölgesinde yukarıya, sırt kısmına doğru kıvrılır. Karın tarafı kirli beyaz veya sarımsı renkte olup granüllüdür. Kesintisiz ince koyu bir bant, sırt ve karın kısmını birbirinden ayırır. Erkeklerinde başın altında dış ses kesesi bulunur. Ayak parmaklarının ucunda yapısmaya yarayan geniş disk şeklindeki yapılar vardır. Bu yapılar sayesinde bitkilere ve ağaçlara kolayca tırmanabilirler. Bu tür genellikle geniş yapraklı ve karışık ormanlar, çayırlık-çalılık alanlar, parklar, bahçeler, göl kıyıları, yavaş akan veya durgun su birikintilerinin olduğu yerler ve bunların çevresindeki bitki topluluklarının yoğun olduğu alanlarda yaşarlar. Gelişimlerini tamamlayan yavrular sudan çıktıklarında otların üzerinde olurlar. Sığırlar bu yavruları fark edemeyip yüzlercesini yediklerinde, kurbağaların derilerinde bulunan zehirden dolayı ishal olurlar ve tıbbi müdahale yapılmazsa su kaybından dolayı ölebilirler. Bu yüzden halk arasında bu kurbağalar zehirli olarak bilinirler. Ama bu kurbağa türünün derisindeki zehrin bir ineği öldürecek güçte olmadığı da aşikârdır. Renklerini bulundukları ortamlara göre dönüştürebildikleri için çok zor fark edilirler. Besinlerini böcekler, sinekler ve örümcekler oluşturur. Karasal bir tür olup sadece üreme döneminde suya girerler. Yumurtalarını su birikintileri, göl, gölet, bataklık ve berrak durgun sulara bırakırlar. Bir dişi 800-1000 adet yumurtayı kümeler halinde su içindeki bitkilere bırakırlar. 1800 metreye ulaşan yükseltideki habitatlarda görülebilirler. Ülkemizde Güney ve Batı Anadolu'da yayılmıştır. Türkiye'nin dışındaysa, bütün Avrupa'da, İsveç, Ukrayna, Beyaz Rusya, Rusya, Azerbaycan, Ermenistan ve israil'e kadar yayılmıştır.

\section{Pelophylax ridibundus (Pallas 1771) Ova Kur- bağası}

Vücut boyları $17 \mathrm{~cm}$ kadardır (Fig. 2). Sırt tarafı yeşilimsi gri, kahverengi ve bu zemin renklerinin üzerinde düzensiz koyu lekeler vardır. Bazılarında sırt ortasında iki gözün ortasından başlayarak arkaya doğru giden ince beyaz bir şerit bulunur. Yaşadıkları ortamlara göre renk ve desen durumlarında değişiklikler olabilir. Karın kıs-

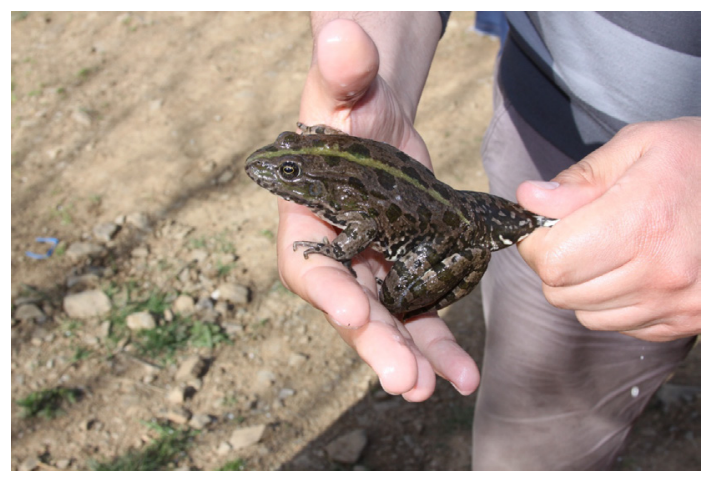

Fig. 2. Antik Kentin İçindeki Gölette ve Çevresindeki Sulak Alanlarda Görülen Ova Kurbağası (Pelophylax ridibundus)

4 Bu türlerin genel özellikleri ve betimlenmesinde Başoğlu - Özeti 1973; Baran 1976; Başoğlu - Baran 1977; 1988; Baran 1983; Yılmaz - Öz 1984; Özeti - Yılmaz 1994; Demirsoy 1996a; 1996b; Baran - Atatür 1998; Öz et al. 1999; Baran 2005; IUCN 2013'ten yararlanılmıştır. 
mı kirli beyaz, sarımsı ve küçük lekelidir. Kulak zarı belirgin ve başın yan tarafında temporal şerit yoktur. Erkeklerinde başın yanlarında iki küçük baloncuk şeklinde olan dış ses kesesi mevcuttur. Bataklık alanlara ve su bazlı yaşama çok iyi adapte olmuş bir tür olup bol bitkili sular, göller, küçük su birikintileri ve ağır akan sularda yaşarlar. Sulak alandan fazla uzaklaşmazlar. Arka ayakları kaslı ve uzun olup perdelidir. Beslenmelerini böcekler, örümcekler ve sinekler oluşturur. Dişileri bir defasında 1000 kadar yumurtayı kümeler halinde sucul bitkilerin arasına bırakırlar. Ülkemizin her tarafında yayılış gösterir. Türkiye'nin dışında İngiltere'nin güneyi, Avrupa'nın tamamında, Finlandiya, Rusya, Azerbaycan, Ermenistan, Gürcistan, Afganistan, Pakistan, Türki cumhuriyetlerinde, ayrıca Çin, Bahreyn, Kıbrıs, İran, Irak, İsrail ve Suudi Arabistan'a kadar yayılış gösterirler.

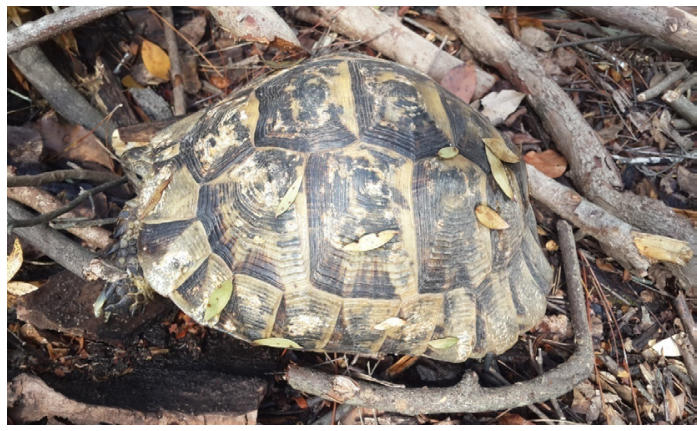

Fig. 3. Antik Kent ve Yakın Çevresinde de Görülebilen, Vejetasyonun Olduğu Karasal Tüm Habitatlarda Sıklıkla Rastlanılabilen Tosbağa (Testudo graeca)
Testudo graeca Linnaeus, 1758 Tosbağa

Boyları $30 \mathrm{~cm}$ kadar olup karapaksı kubbeli bir yapıya sahiptir (Fig. 3).Dişiler erkeklere göre daha küçüktür. Karapaksın üzerindeki keratin plaklar kahverengimsi, siyah, sarı ve gri tonlardadır. Alt tarafı plastron sarımsı olup siyah lekeli olabilir. Ergin bireylerin keratin plaklarının kenarları zamanla siyahlaşır. Genç bireylerde karapaks sarımsı ve açık yeşilimsi renktedir. Plastron erkeklerde arkaya doğru çukurlaşmış, dişilerde ise düzdür. Arka bacakların femur bölgesinde bir çıkıntı bulunur. Kuyruk üstündeki plak tektir.

Sonbaharda havalar soğumaya başladığı zaman kendilerini toprak içine gömerek kış uykusuna yatarlar. Taşlıklı kumlu arazilerde, bahçelerde, kısa çalılık ve otlu arazilerde yayılış gösterirler. Beslenmeleri bitkisel olup bu bitkilerin yaprakları, çiçekleri ve meyveleriyle beslenirler. Bazı zamanlarda da hayvansal gıda ile beslenirler. Doğu Karadeniz dışında bütün Anadolu'da ürerler. Dişi birey, 6-12 adet yumurtasını kumluk arazilerde kazabildiği toprağa bırakır. Yavrular iklim koşullarına göre yumurtadan 3-5 ay içinde çıkabilirler. Proje sahasında karasal habitat tipinde olup, beslenmesine uygun bitkisel vejetasyonun olduğu her yerde bu türe rastlanılabilir. Türkiye dışında Güney Avrupa, Kuzey Afrika ve Güneybatı Asya ile İran'da yayılmıştır.

\section{Stellagama stellio (Linnaeus, 1758) Dikenli keler}

Boyu yaklaşık $40 \mathrm{~cm}$ kadar olup sırt tarafı grimsi, siyahımsı kahverengi ve büyük sarı lekelidir (Fig. 4). Karın tarafı kirli sarı veya sarımsı kahverengidir. Baş yassı ve üstü asimetrik plak ve pullarla örtülüdür. Sırt pullarından bazıları parlak ve mavi renklidir. Baş ve boyun yanlarında diken şeklinde pullar bulunur. Başının altındaki pullar karinalı, karın tarafındakiler düzdür. Kuyruk pulları halkalar şeklindedir. Yaşam alanlarını genellikle kayalık alanlar oluşturur. Bunun yanında taştan örülmüş duvarlardaki küçük taş yığınlarında da görülürler. Nadir olarak ağaca tırmanırlar ve toprak içindeki deliklerde yaşarlar. 16001700 m. yüksekliklere kadar yayılış gösterirler.

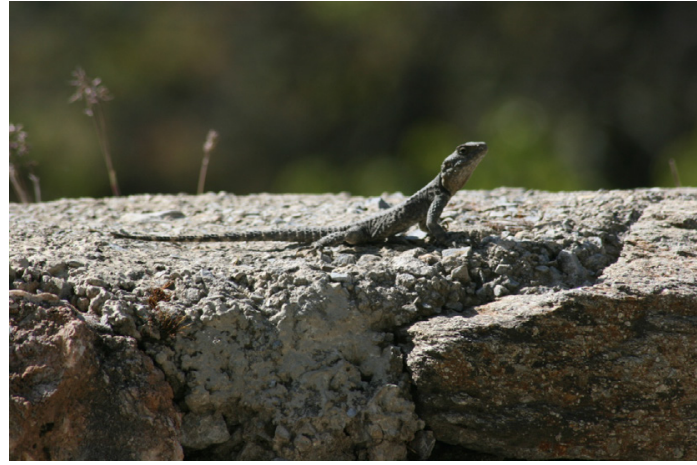

Fig. 4. Antik Kent ve Yakın Çevresinde de Görülebilen, Güneşli Zamanlarda Kayaların ve Taşların Üzerinde Güneşlenirlerken İlenebilen Dikenli Keler (Stellagama stellio) 
Halk arasında koçmar olarak da bilinirler. Genellikle böceklerle bazen de bitkilerle beslenirler. Dişiler 8-14 yumurta bırakırlar. Türkiye'de Batı, Orta, Güney ve Güneydoğu Anadolu bölgelerinde görülür. Proje sahasında gerek antik kent içinde tarihi eserler üzerinde, gerekse yakın çevresindeki kayalıklar üzerinde güneşlenirlerken görülebilirler. Ülkemizin dışında Yunanistan ve Yunan adalarına, ayrıca Makedonya, Kıbrıs, Suriye, Lübnan, İsrail, Irak, Ürdün, Suudi Arabistan ve Mısır’a kadar yayılmıştır.

\section{Chamaeleo chamaeleon (Linnaeus 1758) Bu- kalemun}

Vücut boyu $25-30 \mathrm{~cm}$ olup yanlardan basıktır (Fig. 5). Başın üst tarafında miğfer şeklinde bir çıkıntı vardır. Gözler, ortası delik tek göz kapağı içindedir. Gözler aynı anda birbirinden bağımsız olarak hareket ettiği için farklı yönlere bakabilirler. Vücutlarında bulunan melanin sayesinde rengini değiştirebildikleri için bulundukları ortamda hemen gizlenebilirler. Sirt tarafta koyu leke ve şeritler olsa da renk ve desenini değiştirebildiği için belirli bir renkten bahsedilemez. Ön ayakla-

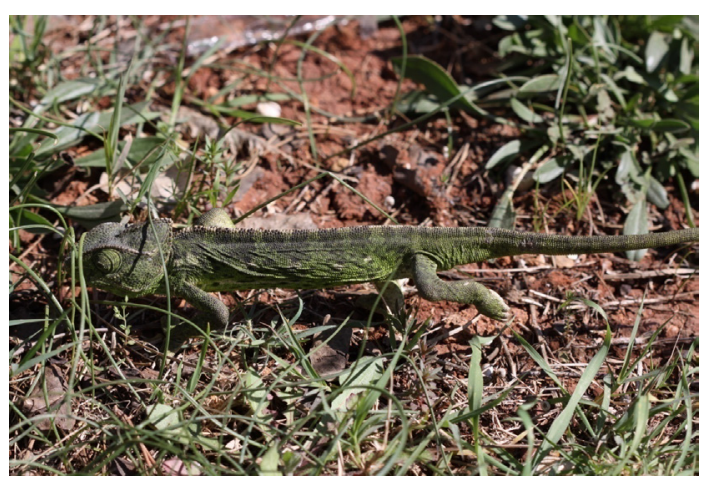

Fig. 5. Antik Kent ve Yakın Çevresindeki Ağaçlık ve Çalılık Alanlarda Görülen Bukalemun

(Chamaeleo chamaeleon) rındaki parmakların iç tarafta 3'ü, dış tarafta 2'si birleşmiş olup arka ayaklarında ise tam tersi durum söz konusudur. Parmaklar bu yüzden yürümekten çok kavramaya yarar niteliktedir. Kuyruklarını daha çok daldan dala geçerken tutunma organı olarak kullanırlar. Genellikle ağaçlık ve makilik alanlarda yaşar, parmakları ve kuyruğu ile dallara tutunarak oldukça yavaş hareket ederler. Avlarını yakalamak için uzun ve ucu yapışkan olan, yaklaşık 18 cm'ye kadar uzanabilen dillerini kullanırlar. Dilinin kaide kısmı alt çenenin ön tarafındadır. Dilini alt çeneye katlarlar. Böcekler ve sineklerle beslenirler. Dişi birey bir defasında 2044 yumurtayı toprağa bırakır. Yavruların eşeysel olgunluğa erişmesi birkaç yıl alabilir. Ülkemizde Ege Bölgesi'nde İzmir'den başlayıp sahil boyunca ve Akdeniz Bölgesi'nin sahil bandında bulunur. 700 m yüksekliklere kadar yayılış gösterirler. Türkiye'nin dışında İspanya, Portekiz, İtalya, Malta, Yunanistan, Kıbrıs, Ortadoğu, Kuzey Afrika ve Batı Sahra'ya kadar yayılış gösterirler.

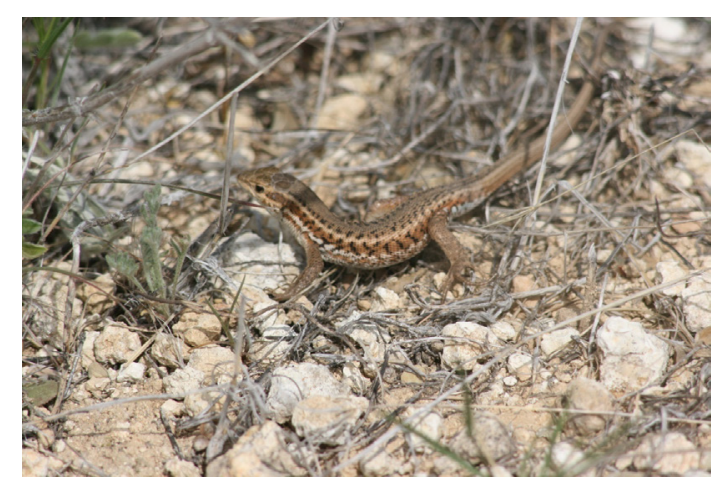

Fig. 6. Antik Kent ve Yakın Çevresinde de Açık Alanlarda Görülen Tarla Kertenkelesi (Ophisops elegans)
Ophisops elegans (Menetries 1832) Tarla Kertenkelesi

Vücut boyu yaklaşık olarak $15-18 \mathrm{~cm}$ olabilen, vücut yapısına göre kuyruğu uzun olan küçük bir kertenkeledir (Fig. 6). İki göz kapağı birleşerek yılan gözü gibi saydam bir yapı oluşturur. Bundan dolayı göz kapağı yok zannedilir. Sırt tarafı gri ve kahverengi olup siyah lekelidir. Sırtta, gözün hemen arkasından iki beyaz çizgi kuyruğa kadar uzanır. Ayrıca alt ve üst çenenin birleştiği yerden başlayan ön ve arka ayakların arasında lateral olarak devam eden beyaz bir çizgi daha vardır. Başın ön üst tarafında boyuna bariz bir çukurluk mevcuttur. Alt tarafı beyazdır. Az bitkili açık alanlarda, taşı ve topraklı zeminlerde, step alanlarda 2000 m'ye kadar olan yüksekliklerde yaşarlar. Genellikle böceklerle beslenirler. Dişi, 2- 
6 adet yumurta bırakır. Yurdumuzda Trakya, Batı, Güney, Orta, Doğu ve Güneydoğu Anadolu'da yaşarlar. Türkiye'nin dışında; Yunanistan ve bazı Yunan adalarına, Kıbrıs, Gürcistan, Ermenistan, Azerbaycan, Bulgaristan, İran, Irak, Suriye, Lübnan, İsrail, Ürdün, Cezayir, Libya, Mısır, Pakistan ve Hindistan'a kadar yayılış gösterirler.

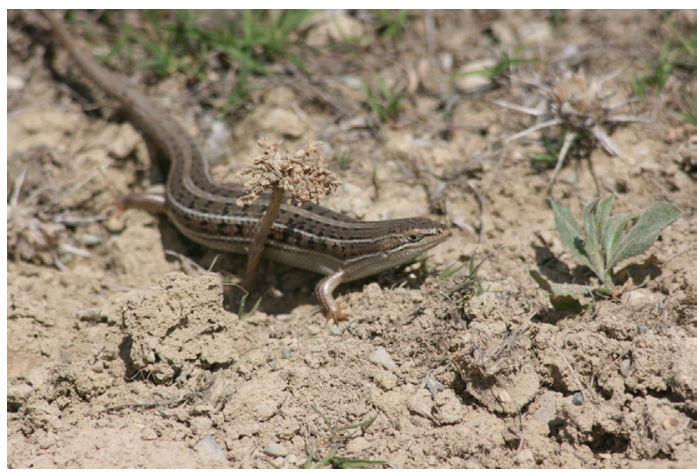

Fig. 7. Antik Kent ve Yakın Çevresinde Çayırlık ve Otluk Alanlarda Görülen Şeritli Kertenkele (Trachylepis vittata)

Trachylepis vittata (Oliver 1804) Şeritli Kertenkele

Vücut boyu yaklaşık $20 \mathrm{~cm}$ kadar olup vücut ince yapılıdırlar (Fig. 7).Vücutlarının üstü kahverengi ve zeytin yeşili rengindedir. Vücut üstünde, vücut boyunca yani baş kısmından kuyruğa doğru uzanan açık renkli 3 şerit vardır. Ayrıca vücudun yanlarında açık renkli birer çizgi ve bu çizgilerin arasında koyu lekeler bulunur. Karın kısmı sarımsı beyaz renkte olup açık yeşil renkte ve lekesiz de olabilirler. Meralıklarda, yoğun bitki örtüsünün bulunduğu alanlarda, çalılık, taşık ya da seyrek ağaçlık bölgelerde, kırsal bahçelerde ve açık arazilerde yaşarlar. Bitkilerin köklerinde, çalıların diplerinde ve taş altlarında gizlenirler. Genellikle böceklerle beslenirler. Yüksekliği 1700 m'ye kadar olan yüksekliklerde yaşayabilirler. Dişi birey 3 ila 6 yavru doğurabilir. Türkiye'de Orta, Güney, Güneybatı Anadolu ve Güneydoğu Anadolu Bölgesi'nde, habitatın uygun olduğu yerlerde yaşarlar. Türkiye'nin dışında İran, Irak, Kıbrıs, Suriye, Lübnan, İsrail, Ürdün, Mısır, Cezayir, Libya ve Tunus'a kadar yayılış gösterirler.

\section{Caretta caretta (Linnaeus, 1758) Deniz Kaplumbağası}

Deniz kaplumbağalarının genel özellikleri dikkate alındığında; ülkemiz kıyılarında sıklıkla yuva yapan ve gruba adını veren deniz kaplumbağası Caretta caretta (Linnaeus 1758) (Deniz kaplumbağası) türüdür (Figs. 8-10). Deniz kaplumbağalarının sadece ergin dişileri üreme sezonunda yuva yapmak amacıyla kumsala çıkar, erkek bireyler ise kumsala çıkmadan hayatlarını denizde geçirirler. Dişi kaplumbağalar 2-4 yılda bir yumurta bırakırlar. Türkiye'deki yuvalama dönemleri Mayıs, Haziran, Temmuz ve Ağustos aylarıdır. Kumsala çıkan dişilerin tamamı yumurta bırakmazlar. Bunun iki türlü nedeni olabilir; dişinin insan, predatör veya çevresel faktörler tarafından rahatsız edilmesi veya uygun yuvalama alanı bulamaması. Yuva yapmaya çıkan kaplumbağaların karapaksları üzerinde ektoparazit olan Balanus sp. Ve Lepas sp. bulunabilir. Ergin bireylerde karapaks (sırt kabuğu) oval şekilli ve arkaya doğru daralmıştır. Ortalama olarak 70-75 cm boyunda ve de 50-55 cm genişliğindedirler. Başları oldukça büyüktür ve morfolojik olarak üçgene benzer (Fig. 8). Ancak bu büyüklük büyük beyine sahip olduklarını göstermez, aksine kafatasındaki boşluk çeneleri kapsayan kaslar tarafından kullanılır. Pasifik ve Hint okyanuslarında yaşarlar. Genel renklenme dorsalde kırmızımsı kahverengi, ventralde kremsi sarı renklidir. C. mydas türünden sağlam bir kabuk yapısı, gözleri ile burun delikleri arasında kalmış iki çift prefrontal plak ve kostal plak sayısının 5 çift olmasıyla kolayca ayırt edilebilirler. Karapaksta beş çift kostal plak, plastronda karapaksla bağlantılı ve geniş üç çift inframarginal plak, her bir üyede iki tırnak ve kahverengimsi kırmızı renklenme karakteristik özellikleridir.

Yumurta bırakmak için dişi birey, yumurtlayacağı kumsala hava karardıktan sonra çıkar. Dişinin kumsala çıkışı kumsaldaki izlerden de anlaşılabilir. Önce vücudunu gizleyeceği bir gövde çukuru, sonra da yumurta çukuru açarak yumurtalarını bırakmaktadır. Genelde yumurta sayısı 70-150 
adet olmakla birlikte, aynı türün bireylerine göre farklılık göstermektedir. Yumurtalarını bıraktıktan sonra ergin dişi, yuvasını kapatıp bir gövde çukuru bırakarak tekrar denize döner. Ergin dişinin yuvalama süresi 1-2 saati bulabilmektedir. Yumurtaları genellikle küresel, beyaz, yumuşak, mukus kaplı ve ping pong topu büyüklüğündedir (yaklaşık 40 mm çapında ve 40 gr ağırlığında). Ayrıca yumurtalar arasında küçük, oval şekilli veya ikili yumurtalara da rastlanılabilir. Bir yuvaya bırakılan yumurta sayısı değişken olmakla birlikte ortalama 70-80 civarındadır. Kuluçka süresi ise 1,5 - 2 aydır. Predatörler tarafından tahrip edilmemiş, bozulmamış yumurtalardan yaklaşık 2 ay sonra yavrular çıkar. Yuvadan çıkan yavruların bir kısmı denize ulaşırken bir kısmı predatörler ve çevresel faktörler tarafından denize ulaşmadan tahrip edilirler. Denize ulaşan yavruların bir kısmı da buradaki predatörler olan yırtıcı balıklar, kuşlar ile ergin kaplumbağalar tarafından avlanırlar. Yavrudan ergin döneme gelene kadar beslenme alanlarına göç ederler. Erginlik dönemlerinde ise beslenme ve yuvalama alanları arasında göçler söz konusudur. Ergin bireylerin kaç yıl yaşadıkları konusunda değişik görüşler (30-50 yıl) mevcuttur

Ergin erkekler dişilerden daha uzun bir kuyruğa, daha uzun ve geriye kıvrılmış tırnaklara sahiptir. Ergin öncesi formlarında morfolojik olarak eşeysel ayrım mümkün değildir. Ama erginlerde eşeysel dimorfizm görülür.

Yavru ve genç Caretta caretta bireyleri yüzeyde akıntı çizgilerinde toplanan makroplanktonlarla beslenirler. Ergin bireyler özellikle yumuşakçalarla (Molusca) beslenmeyi tercih ederler. Etoburdurlar, sünger, denizanası, at nalı yengeçleri ile istiridyeleri de yerler. Geniş bir kafa, oldukça gelişmiş çene kasları ve kuvvetli gagaları sayesinde avlarını kolayca parçalarlar.

Esaret altında yetiştirilen deniz kaplumbağaların 6-7 yıl içerisinde eşeysel olgunluğa ulaşacağı tahmin edilmektedir ${ }^{5}$. Özgür olanların ise M. T. Mendonça'ya göre ${ }^{6} 10-15$ yıl; G. R. Zug ve arkadaşlarına göre $14-19$ yıl; N. B. Frazer'a göre 22 yıl; N. B. Frazer ve L. M. Ehrhart'a göre ise eğrilerden elde edilen bilgilere dayanılarak 12-30 yıl arasında olgunlaşacağı tahmin edilmektedir.

Deniz kaplumbağalarının çiftleşmesi, yuvalama başlangııından birkaç hafta önce yuvalama kumsalı yakınları veya özel toplanma alanlarında meydana gelebilir. Birbirine sıkıca sarılmış çiftlerin çoğunlukla suyun yüzeyinde kopulasyonu gerçekleştirmesiyle birlikte su altında da birleşmeler rapor edilmiştir ${ }^{10}$. Dişi bireylerin kumsala çıkışlarının bazıları yuva ile sonuçlanabileceği (yuvalı çıkış-yuva) gibi, bazıları da yuva ile sonuçlanmayabilir (yuvasız çıkış - yalancı çıkış). Bu tip çıkışların değerlendirilmesi kumsalın yuvalama açısından uygunluğu ve çevresel faktörler açısından önemli ipuçları verebilir. Deniz kaplumbağaları aynı yuvalama sezonunda birden fazla yuvalama yapabilirler. Aynı sezonda iki yuvalama arasında geçen zaman yaklaşık iki haftadır. Ayrıca, deniz kaplumbağaları genel olarak 2-3 yılda bir yuvalama yaparlar.

Gerek kuluçka, gerekse yavru döneminde ciddi predasyon riskleri söz konusudur. Bazı kumsallarda tilki, köpek, domuz, kum yengeçleri vb. predatörler yumurtaları ve yavruları tahrip etmektedirler. Bunun yanında rüzgâr-dalga erozyonu, kum alımı, araç trafiği, tatilcilerin faaliyetleri, kum yığılmaları vb. faktörler kuluçka döneminde yuvaların tahribatına neden olabilecek diğer et-

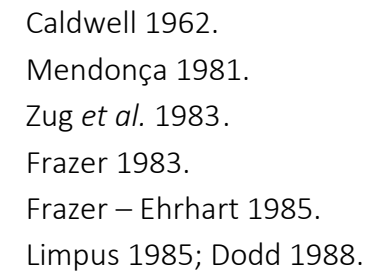


menlerdir. Martılar ise özellikle yavruları avlamaları nedeniyle kuluçka sonrası predasyon faktörü olarak etkindirler.

Kuluçka başarısı ve hayatta kalma oranlarına, dolayısıyla popülasyonun başarısına etki eden faktörler bölgesel ve zamansal olarak değişiklik gösterir. Doğal faktörler (aşırı yağmurlar, rüzgârdalga erozyonu, sıcaklık farkları gibi baskın çevresel faktörler ile besin miktarı ve kalitesi) ve antropojenik etkiler (turizm faaliyetleri, kum alımı ve kumsal yapısının kalıı olarak değiştirilmesi vb.) popülasyonun başarııını doğrudan etkileyen en önemli unsurlardır. Bunun yanında kumun kimyasal yapısı, nem, sıcaklık, gaz değişimi ve predatörlerin varlığı başarıyı doğrudan veya dolaylı olarak etkileyebilir ${ }^{11}$. Yumurtlama sahillerindeki insan varlığı ve yapay ışık kaynakları, yuvalama yapmak için denize çıkmış dişiyi rahatsız eder ve denize dönmelerine sebep olabilir ${ }^{12}$. Bu durum turizm bölgelerinde en önemli faktör olarak karşımıza çıkmaktadır.

Yavrular zaten esnek olan yumurta kabuklarını yırttıktan sonra karapakslarının düzelmesi için yuva içinde 20-26 saate kadar hareketsiz kalırlar. Yuvayı terk etme ise yumurtadan çıtıktan 1-7 gün (ortalama 3 gün kadar) sonra, yavruların yüzeye doğru tırmanmalarıyla gerçekleşir ${ }^{13}$. Yavruların yuvadan çıkışları çoğunlukla kum yüzey sıcaklığının düştüğü gece saatlerinde meydana gelir. Yuvadaki bütün yavrular aynı zamanda çıkmayabilir. Bu durumda takip eden gecelerde de gruplar halinde yavru çıkışı devam eder. Yavruların çıkışı kumsaldaki izlerden de takip edilebilir (Fig. 8) Yuvadan çıkmış yavrular ufuk aydınlığını ve yıldızlar ile varsa ayın deniz üzerinde oluşturduğu akisleri kullanarak denize doğru yönlenirler. Bu durumda, plaj gerisinde olan bir ışık yavru-

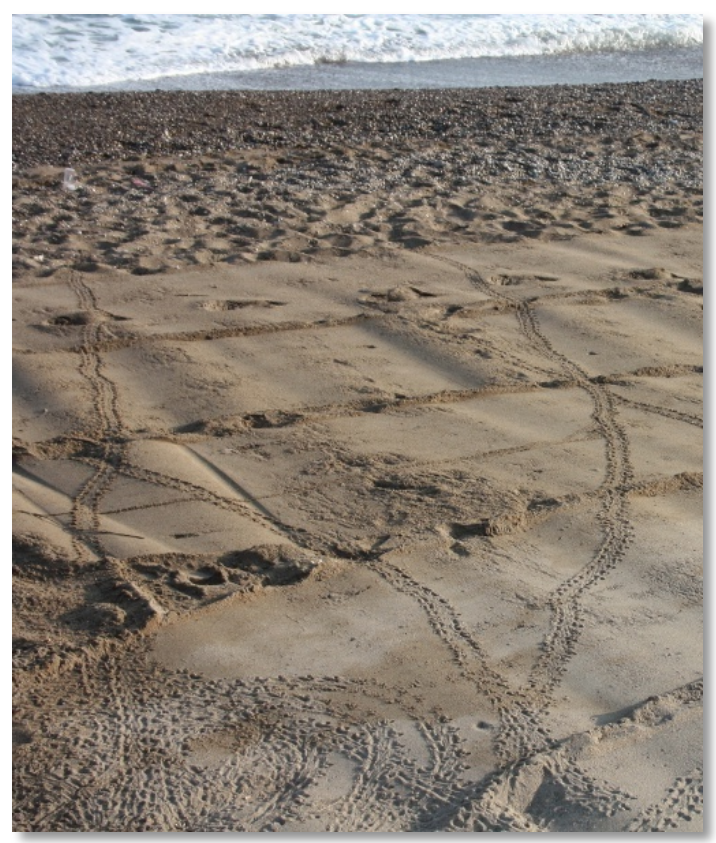

Fig. 8. Yuvadan Çıkan Yavruların Kumsal Üzerindeki Izleri ların yönlerini şaşırmasına ve de ölümlerine neden olabilir. Denize ulaşan yavrular "yüzme çılgınlığı" denen ve yaklaşık 20 saat süren bir dönemde durmaksızın yüzerler ${ }^{14}$.

Denize ulaşan her yavru yaşayıp, yetişkinliğe ulaşamaz. Bu oranın yaklaşık olarak \%1 civarında olduğu tahmin edilmektedir. Özellikle yavru ölümlerinin yuvadan çıkıştan sonra kumsalda ve yüzmenin ilk birkaç gününde fazla olduğu kabul edilir. Yengeçler, tilkiler, köpekler, yakın kıyı balıkları ve köpek balıkları en önemli predatörleridir. Yavrular kumsal ışılandırmaları sebebiyle oluşan yanlış yönlendirmeler sonucu ölebilir. Deniz yerine otel vb. ışıklara yönelen yavrular denize ulaşamayıp kumun sıcaklığınla kuruyarak ölebilmektedirler. Tenha kumsallardaki en önemli sorunlardan biri ise predasyondur. Predatörler gerek yuvaları kazıp yumurtaları tahrip etmekte, gerekse yavruları yemektedirler. Hastalık, şiddetli açlık ve hipo-

termi ile gelişen soğuk sersemliği de ölümlere sebep olabilmektedir. Sanayi atıkları, katran, yağ

11 Türkozan - Baran 1996; Türkozan 1998; Türkozan - Durmuş 2001; Türkozan et al. 2003.

12 Dodd 1988.

13 Demmer 1981; Dodd 1988.

14 Salmon - Wyneken 1987. 
atığı, plastik atıklarının yutulmasından da ölümler meydana gelmektedir. Ayrıca bot çarpması, bilinçli olarak insanlar tarafından avlanmaları ve çeşitli ağlara takılmaları sonucu ölümler de gerçekleşmektedir. Yine çeşitli nedenlerle (kumsala araçla giriş, plajda yuva üzerine şezlong konulması, kum erozyonu ve yığılma vb) yavrular yuva içerisinde sıkışabilmektedirler.

Bir şekilde yaşamını sürdüren ve yetişkinliğine ulaşan bireyler okyanuslara ulaşabilirler. Açık okyanuslarda deniz kaplumbağaları güçlü akıntılara maruz kalır. Özellikle de kafalarını suyun üstüne sadece birkaç santim çıkarabilir. Bu kadar engele rağmen deniz kaplumbağaları binlerce kilometre göç ederek doğdukları kumsallara geri dönerler. Yön bulma duygularının bu kadar gelişmiş olmasında deniz kaplumbağalarının manyetik dalgaları algılayabilmesinin rolü olduğu düşünülmektedir.

Deniz kaplumbağalarının beslenme alanlarından yuvalama bölgelerine olan çok uzun mesafeli göçü hayvanlar âleminin en ilginç göçlerindendir. Erişkin dişilerin kendi doğdukları bölgelere göç etmeleri ise daha da dikkat çekicidir. Bu göçün yuvadan ilk çıkışla başladığını biliyoruz. Atlantik Okyanusu ve Karayip Denizi'nde birçok yavru körfez akıntılarına kapııır. Genç bireyler birkaç yıllarını kıyı yakınlarında geçirirler. Yetişkin kaplumbağaların üreme dönemi dışında yaşamlarını sürdürdükleri bölge Atlantik Okyanusu orta sularıdır. Çiftleşme döneminde dişi ve erkek bireyler kumsallara doğru uzun göçlerine başlarlar. Bu süreçte popülasyonlar Atlantik Okyanusu, Hint Okyanusu ve Pasifik Okyanusu'nda gözlemlenmiştir.

Phaselis antik kentinin doğal bir sahili olan Bostanlık Koyu Kumsalı Caretta caretta türü deniz kaplumbağaları için genel olarak uygun bir kumul yapısına sahiptir. 2014 ve 2015 yıllarında yaptığımı çalışma ve incelemelerde türün dişilerinin yuvalanmak ve yumurtlamak için kumsalı kullandığı tespit edilmiştir. Ergin birey çıkışlarının gerçekleşeceği tahmin edilen 30 Mayıs ile 30 Temmuz 2014 tarihleri arasında yapılan arazi ve ön çalışmada Bostanlık Koyu Kumsalı́nın batı bölümünde toplam 10 adet yuva tespit edilmiş, bu yuvalardan 5'inde yavru çıkışı gerçekleşmiştir. Geri kalan 5 yuva ise predatörler tarafından tahrip edilmiştir. Diğer taraftan turistlerin ve halkın yoğun olarak kullandığı doğu bölümünde ise hiçbir çıkışa rastlanmamıştı ${ }^{15}$.

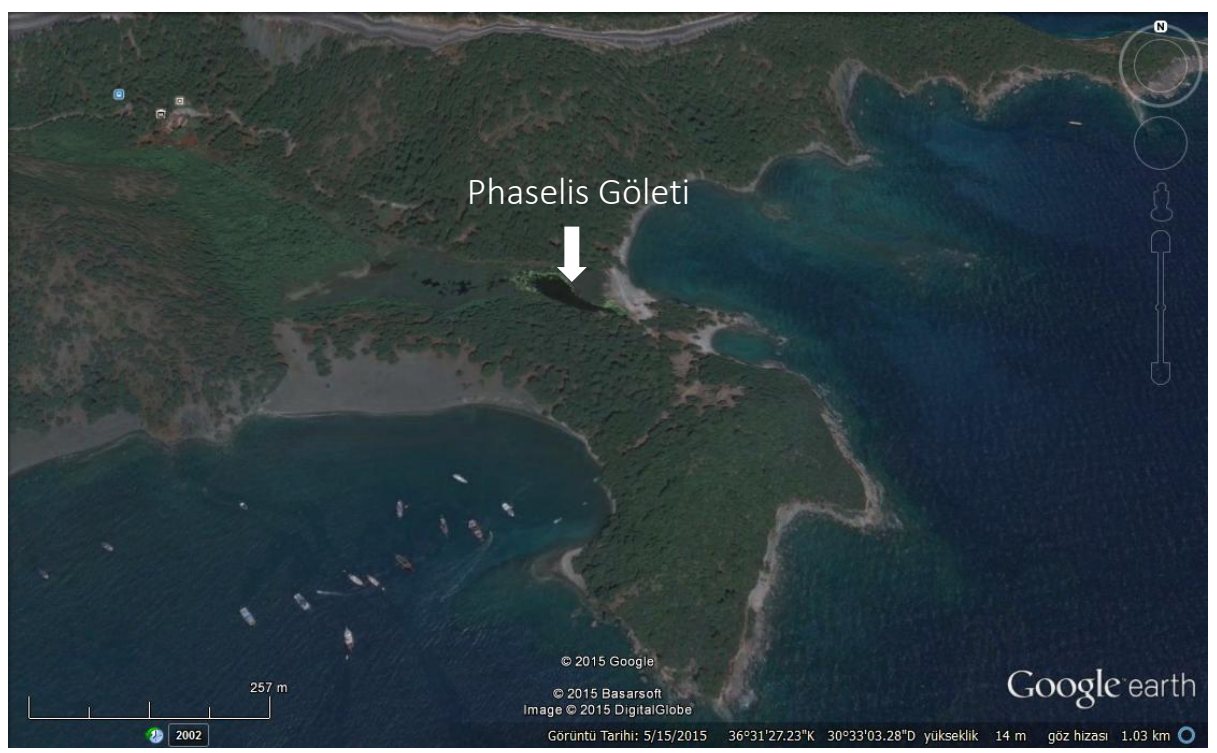

Fig. 9. Phaselis Göleti'nin Konumunu Gösteren Uydu Görüntüsü 


\section{Sonuç}

Sahanın mevcut habitat özellikleri, denizle karanın iç içe olan topografyası ve de kısmen sakin ortamı nedeniyle, Phaselis antik kenti nispeten dar bir alanda çok sayıda türe ev sahipliği yapmaktadır. Bu bakımdan sahadaki mevcut habitat ve biyotopların korunması ve geliştirilmesi büyük önem arz etmektedir. Phaselis antik kenti ve teritoryumu içinde amfibiler ve sürüngenler için olduğu kadar, tüm diğer fauna elemanları için de büyük önem taşıyan Phaselis Göleti yer almaktadır (Fig. 9). Mevcut haliyle denizle ve başka tatlı su kaynaklarıyla bağlantısı kesilmiş olduğundan karasallaşmaya yüz tutmuş gölet, bu haliyle bile su kuşları ve bazı amfibiler için barınma, sığınma ve beslenme ortamı oluşturmaktadır. Özellikle ıslah çalışmaları yapılarak yeniden eski canııı̆ı̆ ve limnetik özelliklerine yakın bir hale getirilebilirse hali hazırda var olan amfibiler için daha zengin ve temiz bir habitat sağlanmış olacaktır. Bu sayede amfibilerden bunları tüketen sürüngen ve kuşlara, zengin hayvan çeşitliği sayesinde de zincirin en üstünde yer alan yırtıcı memelilere kadar birçok taksonun popülasyon yoğunluğunu olumlu etkileyecektir. Hatta Phaselis Göleti Islah edilerek yeniden canlandırılırsa; yakın civarda zar zor varlığını sürdürebilen, suya doğrudan veya dolaylı olarak bağımlı olan başta amfibiler ve su kuşları olmak üzere birçok türün geleceği olumlu yönde değişecektir. 


\section{BIBBLIYOGRAFYA}

Baran - Atatür 1998

Baran 1976

Baran 1983

Baran 2005

Baran et al. 1996

Baran et al. 2001

Baran et al. 2012

Başoğlu - Baran 1977

Başoğlu - Baran 1988

Başoğlu - Özeti 1973

Başoğlu et al. 1994

Bodenheimer 1944

Caldwell 1962

Demirsoy $1996 a$

Demirsoy $1996 \mathrm{~b}$

Demmer 1981

Dodd 1988

Düşen et al 2005

Erdoğan et al. 2002

Erdoğan et al. 2008

Frazer - Ehrhart 1985

Frazer 1983

IUCN 2006
I. Baran - M. K. Atatür, Türkiye Herpetofaunası (Kurbağa ve Sürüngenler). Ankara 1998.

i. Baran, Türkiye Yılanlarının Taksonomik Revizyonu ve Coğrafi Yayılışları. Ankara 1976.

i. Baran, "Güneybatı Anadolu Finike ve Kaş Civarının Herpetolojisi". Doğa Bilim Dergisi 7 (1983) 59-66.

i. Baran, Türkiye Amfibi ve Sürüngenleri. Ankara 2005.

I. Baran, S. H. Durmuş, E. Çevik, S. Üçüncü - A. F. Canbolat, "Türkiye Deniz Kaplumbağaları Stok Tespiti”. Turkish Journal of Zoology 16 (1996) 119-139.

i. Baran, A. Özdemir, Ç. Ilgaz - O. Türkozan, "Impact of Some Invertebrates on Eggs and Hatchlings of the Loggerhead Turtle, Caretta caretta, in Turkey". Zoology in the Middle East 24 (2001) 9-17.

i. Baran, Ç. Ilgaz, A. Avcı, Y. Kumlutaş - K. Olgun, Türkiye Amfibi ve Sürüngenleri. Ankara 2012.

M. Başoğlu - i. Baran, Türkiye Sürüngenleri, I. Cilt: Kaplumbağalar ve Kertenkeleler. İzmir 1977.

M. Başoğlu - I. Baran, Türkiye Sürüngenleri. II. Cilt: Yılanlar. İzmir 1988.

M. Başoğlu - N. Özeti, Türkiye Amfibileri. İzmir 1973.

M. Başoğlu, N. Özeti - I. Yılmaz, Türkiye Amfibileri. İzmir 1994.

F. S. Bodenheimer, "Introduction into the Knowledge of the Amphibia and Reptilia of Turkey". Rev. Fac. Sci. Univ. Istanbul 9 (1944) 1-78.

D. K. Caldwell, Growth Measurements of Young Captive Atlantic Sea Turtles in Temperate Waters. Los Angeles 1962.

A. Demirsoy, Türkiye Omurgalıları: Amfibiler. Ankara 1996.

A. Demirsoy, Türkiye Omurgalıları: Sürüngenler. Ankara 1996.

R. J. Demmer, The Hatching and Emergence of Loggerhead Turtle (Caretta caretta) Hatchlings. Unpublished Master Thesis, University of Central Florida. Florida 1981.

J. C. K. Dodd, "Synopsis of the Biological Data on the Loggerhead turtle Caretta caretta (Linnaeus 1758)". U. S. Fish and Wildlife Service Biological Report 88 (1988) 1-110.

O. Düşen, M. R. Tunç, A. Aslan - H. B. Sert, "Flora ve Fauna". Eds. N. Çevik, B, Varkıvanç - E. Akyürek, Beydağları Yüzey Araştırmaları IX. Antalya (2005) 131-147

A. Erdoğan, M. Öz, S. Düşen, H. Sert - M. R. Tunç, "Antalya Yamansaz Gölü ve Yakın Çevresinin Avifaunası ve Herpetofaunası". Ekoloji Çevre Dergisi 10/ 43 (2002) 33-39.

A. Erdoğan, M. Öz, H. Sert, M. R. Tunç - M. Yavuz, Arkeolojisi, Tarihi, Doğası ve Tarımıyla Kumluca Rhodiapolis. Antalya 2008.

N. B. Frazer - L. M. Ehrhart, "Preliminary Growth Models for Green, CheIonia mydas, and Loggerhead, Caretta caretta, Turtles in the Wild". Copeia 1 (1985) 73-79.

N. B. Frazer, "Survivorship of Adult Female Loggerhead Sea Turtles, Caretta caretta, Nesting on Little Cumberland Island, Georgia, USA". Herpetologica 39 (1983) 436-447.

IUCN, Species Survival Commission. Guidelines for using the IUCN Red List Categories and Criteria. Ver. 6.2. Prepared by the Standards and Petitions Working Group of the IUCN SSC Biodiversity Assessment SubCommittee in December 2006. 
208

IUCN 2013

IUCN 2015-4

Kumlutaş et al. 2004a

Kumlutaş et al. 2004b

Limpus 1985

Mendonça 1981

Mertens 1952

Öz et al. 1999

Öz et al. 2010

Özeti - Yılmaz 1994

Salmon - Wyneken 1987

Türkozan - Baran 1996

Türkozan - Durmuş 2001

Türkozan 1998

Türkozan et al. 2003

Yavuz - Tunç 2015a

Yavuz - Tunç 2015b

Yılmaz - Öz 1984

Zug et al. 1983
Mehmet Rızvan TUNÇ - Mustafa YAVUZ

IUCN, Red List of Threatened Species. Kaynak: www.redlist.org. IUCN 2015-4. Red List of Threatened Species. Version 2015.3. Kaynak: www.iucnredlist.org

Y. Kumlutaş, M. Öz, H. Durmuş, M. R. Tunç, A. Özdemir - S. Düşen, “On Some Lizard Species of the Western Taurus Range". Turkish Journal of Zoology 28 (2004) 225-236.

Y. Kumlutaş, A. Özdemir, Ç. Ilgaz - M. Tosunoğlu, "The amphibian and reptile species of Bozdağ (Ödemiş)". Turkish Journal of Zoology 28 (2004) 317-319.

C. J. Limpus, A Study of the Loggerhead Sea Turtle, Caretta caretta, in Eastern Australia. Unpublished PhD Dissertation, University of Queensland. Brisbane 1985.

M. T. Mendonça, "Comparative Growth Rates of Wild Immature Chelonia mydas and Caretta caretta in Florida". Journal of Herpetology 15/4 (1981) 447-451.

R. Mertens, "Amphibien und Reptilen aus der Türkei". Revue de la Faculté des Sciences de I'Université d'Istanbul 17 (1952) 41-75.

M. Öz, Y. Kumlutaş, H. Durmuş, O. Türkozan, S. Düşen - M. R. Tunç, Batı Torosların Herpetofaunası. TÜBITAK (1996) TBAG-1475 Numaralı Proje.

M. Öz, O. Düşen, M. R. Tunç, "Kurbağalar ve Sürüngenler". Ed. H. Uğurluay, Türkiye'nin Doğa Rehberi. İstanbul (2010) 569-617.

N. Özeti - I. Yılmaz, Türkiye Amfibileri. İzmir 1994.

M. Salmon_- J. Wyneken, "Orientation and Swimming Behavior of Hatchling Loggerhead Turtles Caretta caretta L. During Their Offshore Migration". Journal of Experimental Marine Biology and Ecology 109/2 (1987) 137-153.

O. Türkozan - I. Baran, "Research on the Loggerhead Turtle, Caretta caretta, of Fethiye Beach". Doğa Türk Zooloji Dergisi 20 (1996) 183-188.

O. Türkozan - S. H. Durmuş, "Albino Loggerhead and Green Turtle Hatchlinsgs (Caretta caretta and Chelonia mydas) in Turkey". Zoology in the Middle East 24 (2001) 133-136.

O. Türkozan, Investigation on the Marine Turtle Population of Fethiye and Kızılot Beaches. Yayımlanmamış Doktora Tezi, Dokuz Eylül Üniversitesi. İzmir 1998.

O. Türkozan, Ç. Ilgaz, E. Taşkavak - A. Özdemir, "Hatch Rates of loggerhead Turtles and Physical Characteristics of the Beach at Fethiye, Turkey". Journal of the Marine Biological Association of the United Kingdom 83 (2003) 231-232.

M. Yavuz - M. R. Tunç, "Phaselis Antik Kenti ve Yakın Çevresinin Faunası I". Phaselis I (2015) 143-183.

M. Yavuz - M. R. Tunç, "Fauna”. Ed. T. Korkut, Arkeoloji, Epigrafi, Jeoloji, Doğal ve Kültürel Peyzaj Yapısıyla Tlos Antik Kenti ve Teritoryumu. Ankara (2015) 399-458.

i. Yılmaz - M. Öz, "A New Locality of Mertensiella Luschani Finikensis (Amphibia: Salamandridae)". İstanbul Üniv. Fen. Fak. Mec. B/49 (1984) 85-88.

G. R Zug, A. Wynn - C. Ruckdeschel, "Age Estimates of Cumberland Island Loggerhead Sea Turtles". Marine Turtle Newsletter 25 (1983) 9-11. 